\title{
NEPHELINE FORMATION POTENTIAL IN SLUDGE BATCH 4 (SB4) AND ITS IMPACT ON DURABILITY: SELECTING GLASSES FOR A PHASE 3 STUDY
}

K. M. Fox

T. B. Edwards

D. K. Peeler

January 2006

Process Science and Engineering Section Savannah River National Laboratory Aiken, SC 29808

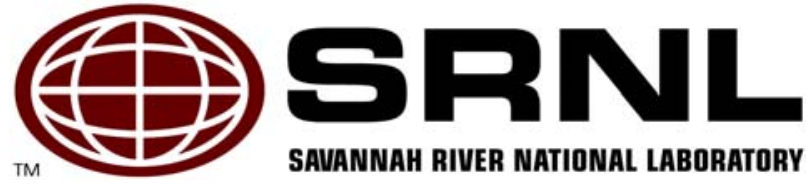


WSRC-TR-2006- 00053

Revision 0

\section{DISCLAIMER}

This report was prepared by Washington Savannah River Company (WSRC) for the United States Department of Energy under Contract No. DE-AC09-96SR18500 and is an account of work performed under that contract. Neither the United States Department of Energy, nor WSRC, nor any of their employees makes any warranty, expressed or implied, or assumes any legal liability or responsibility for the accuracy, completeness, or usefulness, of any information, apparatus, or product or process disclosed herein or represents that its use will not infringe privately owned rights. Reference herein to any specific commercial product, process, or service by trademark, name, manufacturer or otherwise does not necessarily constitute or imply endorsement, recommendation, or favoring of same by WSRC or by the United States Government or any agency thereof. The views and opinions of the authors expressed herein do not necessarily state or reflect those of the United States Government or any agency thereof.

\section{Printed in the United States of America \\ Prepared For U.S. Department of Energy}

The Savannah River National Laboratory is operated for the U.S. Department of Energy by Washington Savannah River Company. 
Key Words: durability, process control, SB4, variability study

Retention: Permanent

\section{NEPHELINE FORMATION POTENTIAL IN SLUDGE BATCH 4 (SB4) AND ITS IMPACT ON DURABILITY: SELECTING GLASSES FOR A PHASE 3 STUDY}

K. M. Fox

T. B. Edwards

D. K. Peeler

January 2006

Process Science and Engineering Section Savannah River National Laboratory Aiken, SC 29808 


\section{REVIEWS AND APPROVALS}

\section{AUTHORS:}

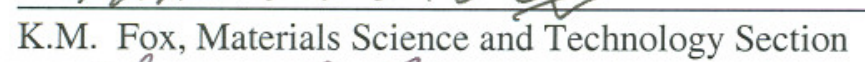

T.B. Edwards, Spatistical Consulting Section

D.K. Peeler, Process Science and Engineering Section
Date

Date

Date

\section{TECHNICAL REVIEWER:}

C.C. Herman, Manager, Process Engineering Technology Group ' Date

\section{APPROVERS:}

D.Ā. Crowley, Manager, Stabilization Sciẹthce Research Group

Date

R.E. Edwards, Manager, Process Science and Engineering Section

Date

V. E. Occhipinti, Manager,

Process Cognizant Engineer - Waste Solidification Engineering

Date 
WSRC-TR-2006- 00053

Revision 0

\section{EXECUTIVE SUMMARY}

Assessment of the likelihood for nepheline formation in Sludge Batch 4 (SB4) glass systems and the potential impact of nepheline on the durability of these systems are part of the frit development effort for SB4. The effect of crystallization on glass durability is complex and depends on several interrelated factors including the change in residual glass composition, the formation of internal stress or microcracks, and the preferential attack at the glass-crystal interface. Perhaps the most significant effects are the type and extent (or fraction) of crystallization and the change to the residual glass composition. A strong increase in glass dissolution (or decrease in durability) has been observed in previous studies in glasses that formed aluminum-containing crystals, such as $\mathrm{NaAlSiO}_{4}$ (nepheline) and $\mathrm{LiAlSi}_{2} \mathrm{O}_{6}$, and crystalline $\mathrm{SiO}_{2}$.

Although it is well known that the addition of $\mathrm{Al}_{2} \mathrm{O}_{3}$ to borosilicate glasses enhances the durability of the waste form (through creation of network-forming tetrahedral $\mathrm{Na}^{+}-\left[\mathrm{AlO}_{4 / 2}\right]^{-}$pairs), the combination of high $\mathrm{Al}_{2} \mathrm{O}_{3}$ and $\mathrm{Na}_{2} \mathrm{O}$ can lead to the formation of nepheline $\left(\mathrm{NaAlSiO}_{4}\right)$. Given the projected high concentrations of $\mathrm{Al}_{2} \mathrm{O}_{3}$ and $\mathrm{Na}_{2} \mathrm{O}$ in SB4 and the likely use of a high $\mathrm{Na}_{2} \mathrm{O}$ based frit to improve melt rate, the potential for formation of nepheline in various SB4 systems continues to be assessed as part of the frit development effort.

Based upon earlier work by Li et al., ${ }^{1}$ glasses that do not satisfy the constraint:

$$
\frac{\mathrm{SiO}_{2}}{\mathrm{SiO}_{2}+\mathrm{Na}_{2} \mathrm{O}+\mathrm{Al}_{2} \mathrm{O}_{3}}>0.62
$$

where the oxides are expressed as mass fractions in the glass, will precipitate nepheline as their primary crystalline phase, hindering the durability of the glass. This constraint is referred to as the nepheline discriminator.

The first phase of this study examined the potential for nepheline formation in SB4 based glasses containing relatively high amounts of $\mathrm{Na}_{2} \mathrm{O}$ and $\mathrm{Al}_{2} \mathrm{O}_{3}$. The glasses produced for Phase 1 were all acceptable in terms of Product Consistency Test (PCT) response regardless of the thermal treatment, with the least durable glass having a normalized release for boron of $2.47 \mathrm{~g} / \mathrm{L}$ (as compared to the Environmental Assessment (EA) glass at $16.695 \mathrm{~g} / \mathrm{L}$ ). Although the glasses were acceptable, the Phase 1 glasses were not designed to challenge the nepheline discriminator value. More specifically, only two Phase 1 glasses were prone to nepheline formation with discriminator values just below 0.62 . These two glasses did show a statistical difference in PCT response between quenched and centerline canister cooled (сc) glasses, but the difference was of no practical concern.

Phase 2 was then undertaken to fully challenge the nepheline discriminator value of 0.62 . Using two updated sludge options from the Closure Business Unit (CBU), 28 glasses were selected to continue the investigation into the ability of the nepheline discriminator to predict nepheline crystallization in SB4 glasses and into the impact of such crystallization on the durability of these glasses. The results of the Phase 2 study suggested that the 0.62 value is a reasonable guide to the potential for nepheline crystallization, particularly for ccc glasses. The study showed that the ccc glasses were provided the kinetic conditions necessary for nepheline crystallization, and that some of these glasses had PCT responses that were above the acceptable limit. The general trend in the Phase 2 data suggested that as waste loading (WL) increased, the value of the nepheline discriminator decreased. Also, the difference in PCT response between quenched and ccc glasses increased. 
The most recent compositional projections from the CBU for SB4 have identified Case 15C Blend 1 as the baseline flowsheet for SB4. ${ }^{2}$ Four candidate frits have been down-selected for this option via a paper study approach ${ }^{3}$ based on operating windows (i.e., waste loading intervals that meet Product Composition Control System (PCCS) Measurement Acceptability Region (MAR) criteria) that are robust to and/or selectively optimal for this sludge option.

For this Phase 3 study, 16 glasses have been selected to complement the earlier work ${ }^{4-6}$ by continuing the investigation into the ability of the above constraint to predict the occurrence of a nepheline primary crystalline phase for SB4 glasses and into the impact of such phases on the durability of the SB4 glasses. The Phase 3 study has two primary objectives. The first is to continue to demonstrate the ability of the discriminator value to adequately predict nepheline formation potential for specific glass systems of interest. The second is to generate additional data that have a high probability of supporting the SB4 variability study. To support these two objectives, glasses were selected to cover WLs which tightly bound the nepheline discriminator value of 0.62 , with the intent of refining this value to a level of confidence where it can be incorporated into offline administrative controls and/or the PCCS to support Slurry Mix Evaporator (SME) acceptability decisions. In addition, glasses targeting lower WLs (35 and $40 \%$ ) will be prepared and analyzed to contribute needed data to the ComPro ${ }^{\mathrm{TM}}$ database in anticipation of a variability study for SB4.

The Phase 3 glasses are to be batched and fabricated using standard procedures. Visual observations and other analytical techniques are to be used, as needed, to assess the presence of crystals with specific interest in the nepheline primary phase. The durability of these glasses (for both quenched and centerline canister cooled versions) is to be measured using the ASTM PCT Method A. The results from these efforts are to be documented in a subsequent report. 


\section{TABLE OF CONTENTS}

$\begin{array}{lr}\text { Executive Summary } & \mathrm{v} \\ \text { List of Tables } & \text { viii } \\ \text { List of Acronyms } & \text { ix } \\ 1.0 \text { Introduction } & 1 \\ 2.0 \text { Task Objectives } & 3 \\ \text { 3.0 SB4 Glass Systems } & 3 \\ \text { 3.1 The SB4 Composition Under Study } & 4 \\ \text { 3.2 Candidate Frits } & 4 \\ \text { 3.3 Potential for Nepheline Formation } & 5 \\ \text { 4.0 Selecting Glasses to Refine the Nepheline Discriminator } & 6 \\ \text { 5.0 Summary } & 11 \\ 6.0 \text { References } & 12\end{array}$




\section{LIST OF TABLES}

Table 3-1. Nominal Composition of SB4 Case 15C Blend 1 as Mass Percents ....................................... 4

Table 3-2. Composition of Candidate Frits (as mass fractions) ............................................................ 5

Table 4-1. Nepheline discriminator values over a range of waste loadings for the four frits studied......... 9

Table 4-2. Compositions of Selected Glasses for SB4 Case 15C Blend 1 (in wt\%) ............................... 10 


\section{LIST OF ACRONYMS}

$\begin{array}{ll}\text { ARP } & \text { Actinide Removal Process } \\ \text { CBU } & \text { Closure Business Unit } \\ \text { CCC } & \text { Centerline Canister Cooled } \\ \text { DWPF } & \text { Defense Waste Processing Facility } \\ \text { EA } & \text { Environment Assessment glass } \\ \text { ComPro } & \text { Composition - Properties database } \\ \text { MAR } & \text { Measurement Acceptability Region } \\ \text { PCCS } & \text { Product Composition Control System } \\ \text { PCT } & \text { Product Consistency Test } \\ \text { SB } & \text { Sludge Batch } \\ \text { SME } & \text { Slurry Mix Evaporator } \\ \text { SRNL } & \text { Savannah River National Laboratory } \\ \text { SRS } & \text { Savannah River Site } \\ \text { TT\&QA } & \text { Task Technical and Quality Assurance (plan) } \\ \text { TTR } & \text { Technical Task Request } \\ \text { WL } & \text { Waste Loading }\end{array}$


WSRC-TR-2006- 00053

Revision 0

\subsection{INTRODUCTION}

The Defense Waste Processing Facility (DWPF) is currently processing Sludge Batch 3 (SB3) as a "sludge-only" composition by combining SB3 with Frit 418, melting the slurry mix of sludge and frit, and pouring the molten glass in stainless steel canisters to create the final waste form for this high-level waste at the Savannah River Site (SRS). In preparation for the qualification and receipt of the next sludge batch, Sludge Batch 4 (SB4), development and definition of the baseline flowsheet were initiated using options from Lilliston ${ }^{7}$ and have progressed to using options provided by Elder ${ }^{8,9}$ and Shah. ${ }^{2}$ These options have been and continue to be evaluated for SB4 in an effort to meet critical Closure Business Unit (CBU) objectives including those associated with the durability of the DWPF glass waste form and the efficiency and effectiveness of the DWPF operation. Critical components of DWPF's operational efficiency and effectiveness include sludge/frit processability, melter attainment (the percentage of time DWPF's melter is pouring), melt rate, waste loading, and canister production rates.

An early yet meaningful assessment of the processability of a sludge option and of the durability of the corresponding waste form for candidate frits at various waste loadings is provided by using predictions generated by property/composition models. The models employed are the same as those used by DWPF's Product Composition Control System ${ }^{10}$ (PCCS), and the investigation of candidate sludge/frit glass systems may be described as a paper study whose purpose is to identify a viable frit or frits for each sludge option being studied. A frit is deemed viable if its composition allows for economic fabrication and if, when it is combined with a sludge option under consideration, DWPF's property/composition models indicate that the combination has an operating window (a waste loading interval over which the sludge/frit glass system satisfies processability and durability constraints) that allows DWPF to meet its goals for waste loading and canister production.

The Savannah River National Laboratory (SRNL) was asked via technical task requests ${ }^{11,12}$ (TTRs) to provide frit development support for SB4. In response, SRNL issued task technical and quality assurance (TT\&QA) plans. ${ }^{13,14}$ Under these plans, subsequent reports were issued that identified candidate frits and assessed their viability for the SB4 options (with and without the actinide removal process (ARP) streams) as provided by Lilliston ${ }^{7}$ (see Peeler and Edwards ${ }^{4,5}$ ) and by Elder ${ }^{8,9}$ (see Peeler and Edwards ${ }^{15}$ ). While these assessments were strictly model-based and included no experimental work, experimental work in support of the SB4 program has been planned and is underway.

As part of the qualification of each sludge batch, there is a requirement to demonstrate that the durability/composition models ${ }^{16}$ in DWPF's PCCS are applicable for the glass system anticipated by the processing of that sludge. This demonstration of applicability typically takes the form of a variability study that involves the making of glasses and the testing via the Product Consistency Test ${ }^{17}$ (PCT) of their durability. The predicted durability is then compared to the measured durability to assess the applicability of the durability/composition models. Another way to assess model applicability involves identifying glasses that are representative of the glass system and that have already been made and tested (i.e., historical data). The model predictions for these glasses could then be compared to the previously recorded PCT results to demonstrate applicability of the durability/composition models. A preliminary assessment of the need for experimental work to support the SB4 variability study has been completed. ${ }^{18}$ This assessment used a systematic approach that was developed and utilized to determine whether or not historical glasses contained within the ComPro ${ }^{\mathrm{TM}}$ database ${ }^{19}$ lie within the projected SB4 compositional region of interest. The results from that assessment suggested that there was a risk of a lack of direct applicability of historical glass/durability data to satisfy the need for a SB4 variability study and reinforced the potential benefit of an experimental program to generate glass compositions and PCT data to complement ComPro ${ }^{\mathrm{TM}}$ and to help meet the intent of the SB4 variability study. 
Given the projected high concentration of $\mathrm{Al}_{2} \mathrm{O}_{3}$ in the SB4 options under consideration and the likely targeting of a glass system (i.e., a SB4/frit combination) with high $\mathrm{Na}_{2} \mathrm{O}$ content to improve melt rate or waste loading, there is a potential for the formation of nepheline for various SB4 glass systems.

Nepheline formation or crystallization raises a concern regarding glass durability.

The effect of crystallization on glass durability is complex and depends on several interrelated factors including the change in residual glass composition, the formation of internal stress or microcracks, and the preferential attack at the glass-crystal interface. Perhaps the most significant effects are the type and extent (or fraction) of crystallization and the resulting change to the residual glass composition. A strong increase in glass dissolution (or decrease in durability) has been observed in previous studies ${ }^{20-25}$ in glasses that formed aluminum-containing crystals, such as $\mathrm{NaAlSiO}_{4}$ (nepheline) and $\mathrm{LiAlSi}_{2} \mathrm{O}_{6}$, and crystalline $\mathrm{SiO}_{2}$.

$\mathrm{Li}$ et al. ${ }^{1}$ indicate that sodium alumino-borosilicate glasses are prone to nepheline crystallization if their compositions projected on the $\mathrm{Na}_{2} \mathrm{O}-\mathrm{Al}_{2} \mathrm{O}_{3}-\mathrm{SiO}_{2}$ ternary fall within the nepheline primary phase field. In particular, glasses with $\mathrm{SiO}_{2} /\left(\mathrm{SiO}_{2}+\mathrm{Na}_{2} \mathrm{O}+\mathrm{Al}_{2} \mathrm{O}_{3}\right)>0.62$, where the oxides are expressed as mass fractions in the glass, do not precipitate nepheline as their primary phase. Using this inequality as a nepheline formation guide or "discriminator," the potential for the formation of this troubling component has been tracked as part of the frit development studies for SB4 and led to the selection of 12 glasses (as Phase 1 of the nepheline study) that were batched and subjected to the PCT. ${ }^{26}$ The results from that study $^{27}$ suggested that a nepheline discriminator value of 0.62 was a useful guide to predict the formation of this primary crystalline phase for the SB4 glass systems. The results also suggested that the presence of nepheline (or other aluminum-containing crystals) in the SB4 glasses had an impact on the durability of glasses but not to the extent that acceptability or predictability was jeopardized. All of the glasses had acceptable durability as determined by comparisons with the Environmental Assessment (EA) glass. ${ }^{28}$ Although the Phase 1 glasses were acceptable, they were not designed to challenge the nepheline discriminator value. More specifically, only two Phase 1 glasses were prone to nepheline formation with discriminator values just below 0.62 . These two glasses showed a statistically significant difference in PCT response between quenched and centerline canister cooled (ссс) glasses, but the difference was of no practical concern.

Phase 2 of the nepheline study complemented the first phase of the work by investigating glass compositions that covered WLs over which nepheline was the only criterion restricting access to higher WLs. ${ }^{6}$ Phase 2 identified 28 additional glasses for study that intentionally challenged the nepheline discriminator value for two of the updated sludge options from the CBU (1.6M Na, 40" SB3 heel and 1.6M Na, 127” SB3 heel ${ }^{8,9}$ ). All 28 glasses were prone to nepheline formation. The results of the Phase 2 study showed that all of the Phase 2 quenched glasses had acceptable normalized boron releases. The quenched glasses showed no sign of nepheline formation (based on PCT response), even at nepheline discriminator values below 0.62. This is consistent with the Phase 1 results. The Phase 2 ccc glasses generally showed an increasing degree of devitrification with increasing WL. This was not unexpected, as the slower cooling provides a thermodynamically favorable glass (i.e., a composition within the nepheline primary phase field) the kinetic opportunity to devitrify. As WL is increased, the concentration of $\mathrm{Na}_{2} \mathrm{O}$ and $\mathrm{Al}_{2} \mathrm{O}_{3}$ in the glass increases, reducing the nepheline discriminator value below the critical level. In addition, $\mathrm{Fe}, \mathrm{Ni}$ and $\mathrm{Cr}$ concentrations also increase, increasing the probability for crystallization of spinels. The PCT showed that the durability of the Phase 2 ccc glasses decreased with increasing WLs. The normalized boron releases for the Phase 2 ccc glasses ranged from $0.89 \mathrm{~g} / \mathrm{L}$ to $40.11 \mathrm{~g} / \mathrm{L}$ as WL was increased over a range of approximately 39-59\%. ${ }^{a}$ Those Phase 2 glasses which were above the benchmark EA glass acceptability limit of $16.695 \mathrm{~g} / \mathrm{L}$ were primarily higher WL glasses with low nepheline discriminator values. These results highlighted the value of the nepheline discriminator for

\footnotetext{
${ }^{\text {a }}$ Note that the PCT results and the WL used were dependent on the particular glass composition. See Peeler et al. ${ }^{29}$ for further detail.
} 
monitoring potential nepheline formation upon сcс, and showed that nepheline formation can indeed raise normalized boron release rates above the acceptable limit in SB4 glasses.

The purpose of this Phase 3 study is to further refine the nepheline discriminator value to a level of confidence where it can be incorporated, if required, into offline administrative controls and/or the PCCS to support Slurry Mix Evaporator (SME) acceptability decisions. The goal is to identify a specific value, or "line in the sand," that identifies the point at which nepheline formation becomes a concern for glass durability. A more fundamental understanding of the nepheline formation phenomenon will allow for advanced prediction of SB4 glass performance and aid in frit development should updates be made to the SB4 flowsheet. Relatively high ( $>45 \%)$ WLs will be included in the study, with the intent of suppressing nepheline crystallization up to WLs that are beyond those expected to be used by DWPF, so that the impact of nepheline formation will no longer be a concern.

All of the Phase 3 glasses will be based on the nominal Case 15C Blend 1 composition, as this currently defines SB4. ${ }^{2, a}$ A group of glasses covering a WL range that is likely to be used by DWPF (35 and 40\% $\mathrm{WL}$ ) also will be prepared and analyzed to contribute needed data to the $\mathrm{ComPro}^{\mathrm{TM}}$ database in anticipation of a variability study for SB4.

There is a discussion of the objectives of this task in Section 2. In Section 3, possible glass systems that are anticipated for SB4 are reviewed, and Section 4 identifies a set of SB4 glass compositions to help support the objectives of this study. The information presented in this report is summarized in Section 5.

\subsection{TASK OBJECTIVES}

The objectives of this task are threefold: Firstly, to further refine the nepheline discriminator value to a level of confidence where it can be incorporated into offline administrative controls and/or the PCCS to support SME acceptability decisions. Glasses will be prepared with waste loadings tightly bracketing a nepheline discriminator value of 0.62 , as this value has been demonstrated in previous reports to be that at which nepheline crystallization can lead to significant differences in durability between quenched and ccc glasses. Secondly, four frit compositions will be included in the testing to provide data for different $\mathrm{Na}$ contents in the frit, which will be important should the projected composition of SB4 be revised based on settling or washing strategy changes. Thirdly, a group of glasses covering a somewhat lower waste loading range (35 and 40\% WL) will be prepared and analyzed to contribute needed data to the ComPro ${ }^{\mathrm{TM}}$ database in anticipation of a variability analysis for SB4. It should be noted that these lower WL glasses are not prone to nepheline formation but will be of significant value in terms of assessing the PCT response in a WL interval of interest to DWPF processing. The results of this study will provide improved guidelines for the avoidance of nepheline crystallization in SB4 glasses and aid in the downselection of frit compositions.

\subsection{SB4 GLASS SYSTEMS}

This section investigates the SB4 option that is currently being considered as part of the frit development effort. $^{2}$ The nominal composition of Case 15C Blend 1 (or SB4) is presented. No introduction of secondary waste streams (e.g., the ARP) is considered in this Phase 3 study. The compositions of select

\footnotetext{
${ }^{a}$ Due to tank settling and washing issues, the strategy outlined by the CBU has evolved into the definition of a SB4 flowsheet and a Sludge Batch 5 (SB5) flowsheet. Typically, four options are provided for a candidate flowsheet which includes Batch 1, Blend 1, Batch 2, and Blend 2. "Batches" refer to projected sludge compositions (prior to blending) that would be qualified. "Blends" refer to projected sludge compositions (after blending with the heel of the previous sludge batch) that would be processed in DWPF.
} 
WSRC-TR-2006- 00053

Revision 0

candidate frits employed during the paper studies are provided, ${ }^{3}$ and the discriminator used to predict the potential for the formation of a nepheline primary crystalline phase is discussed.

\subsection{The SB4 Composition Under Study}

Table 3-1 provides the nominal sludge composition (as mass percents calcine oxides) for Case 15C Blend 1. This composition was selected as it currently defines SB4. ${ }^{2}$ Some uncertainty exists with regard to the composition of the stream that will be transferred to DWPF, but this is not seen as having a significant impact on the stated objectives.

Table 3-1. Nominal Composition of SB4 Case 15C Blend 1 as Mass Percents

\begin{tabular}{|c|c|c|c|c|c|c||}
\hline $\mathbf{A l}_{2} \mathbf{O}_{3}$ & $\mathbf{B a O}$ & $\mathbf{C a O}$ & $\mathbf{C e}_{2} \mathbf{O}_{3}$ & $\mathbf{C r}_{2} \mathbf{O}_{3}$ & $\mathbf{C u O}$ & $\mathbf{F e}_{2} \mathbf{O}_{3}$ \\
\hline 24.806 & 0.126 & 2.387 & 0.150 & 0.212 & 0.060 & 26.565 \\
\hline & & & & & & \\
\hline $\mathbf{K}_{\mathbf{2}} \mathbf{O}$ & $\mathbf{L a}_{\mathbf{2}} \mathbf{O}_{3}$ & $\mathbf{M g O}$ & $\mathbf{M n O}$ & $\mathbf{N a}_{2} \mathbf{O}$ & $\mathbf{N i O}$ & $\mathbf{P b O}$ \\
\hline 0.344 & 0.108 & 2.495 & 5.480 & 22.080 & 1.577 & 0.091 \\
\hline & & & & & & \\
\hline $\mathbf{S O}_{4}$ & $\mathrm{SiO}_{2}$ & $\mathbf{T h O}_{2}$ & $\mathbf{T i O}_{2}$ & $\mathbf{U}_{3} \mathbf{O}_{\mathbf{8}}$ & $\mathbf{Z n O}$ & $\mathbf{Z r O}_{2}$ \\
\hline 1.338 & 4.113 & 0.066 & 0.027 & 7.640 & 0.098 & 0.237 \\
\hline
\end{tabular}

\subsection{Candidate Frits}

The compositions of the frits considered in this study, including two frits considered during the earlier frit development efforts ${ }^{15}$ are provided in Table 3-2. These frits are currently considered the primary candidates for SB4 based on previous assessments of projected operating windows and melt rate. ${ }^{3,30}$ Frits 418 and 425 have concentrations of $\mathrm{B}_{2} \mathrm{O}_{3}$ and $\mathrm{Li}_{2} \mathrm{O}$ that are fixed at $8 \mathrm{wt} \%$, with only the $\mathrm{Na}_{2} \mathrm{O}$ and $\mathrm{SiO}_{2}$ concentrations varying. These frits stem from the system referred to as a "sliding $\mathrm{Na}_{2} \mathrm{O}$ scale," which has been developed to accommodate potential $\mathrm{Na}_{2} \mathrm{O}$ concentration differences in the sludge as a result of varying blending and/or washing strategies being considered. A more detailed discussion of the "scaled" approach and of the complete set of candidate frits considered is provided in Peeler and Edwards. ${ }^{15}$

Frits 501 and $502^{\mathrm{a}}$ were developed in anticipation of even higher $\mathrm{Na}_{2} \mathrm{O}$ contents in SB4 due to reduced washing operations and/or blending. Since nepheline formation becomes a concern as $\mathrm{Na}_{2} \mathrm{O}$ is increased, the $\mathrm{Na}_{2} \mathrm{O}$ content of these additional frits is reduced. $\mathrm{Li}_{2} \mathrm{O}$ is added to help minimize any negative impact the reduction in $\mathrm{Na}_{2} \mathrm{O}$ may have on melt rate, as melt rate is related to the total alkali content. ${ }^{30}$ These adjustments should move the WL where nepheline crystallization occurs to higher levels.

\footnotetext{
${ }^{a}$ Please note that Frits 501 and 502 were previously referred to as Frits 418-m1 and P3-1, respectively, in the earlier studies. $^{3}$ The names were changed when these frits became primary candidates for SB4 and/or SB5.
} 
WSRC-TR-2006- 00053

Revision 0

Table 3-2. Composition of Candidate Frits

(as mass fractions)

\begin{tabular}{||c|c|c|c|c||}
\hline Frit ID & $\mathbf{B}_{\mathbf{2}} \mathbf{O}_{3}$ & $\mathbf{L i}_{\mathbf{2}} \mathbf{O}$ & $\mathbf{N a}_{\mathbf{2}} \mathbf{O}$ & $\mathbf{S i O}_{2}$ \\
\hline 418 & 0.08 & 0.08 & 0.08 & 0.76 \\
\hline 425 & 0.08 & 0.08 & 0.10 & 0.74 \\
\hline 501 & 0.09 & 0.10 & 0.05 & 0.76 \\
\hline 502 & 0.08 & 0.11 & 0.05 & 0.76 \\
\hline
\end{tabular}

\subsection{Potential for Nepheline Formation}

The results of a study by $\mathrm{Li}$ et al. ${ }^{1}$ indicated that sodium alumino-borosilicate glasses are prone to nepheline crystallization if their compositions projected on the $\mathrm{Na}_{2} \mathrm{O}-\mathrm{Al}_{2} \mathrm{O}_{3}-\mathrm{SiO}_{2}$ ternary fall within the nepheline primary phase field. In particular, glasses that satisfy the constraint:

$$
\frac{\mathrm{SiO}_{2}}{\mathrm{SiO}_{2}+\mathrm{Na}_{2} \mathrm{O}+\mathrm{Al}_{2} \mathrm{O}_{3}}>0.62
$$

where the oxides are expressed as mass fractions in the glass, do not precipitate nepheline as their primary phase. The impact of the application of this guide or discriminator on the operating windows of the SB4 glass systems studied to date is discussed in previous reports. ${ }^{15,29}$ In those studies, the discriminator was used as defined by Equation 1 (i.e., 0.62 was used as the critical value as established by Li et al. ${ }^{1}$ and recommended by Peeler et al. ${ }^{27}$ for SB4). The current study will refine and confirm the critical value of the nepheline discriminator. 
WSRC-TR-2006- 00053

Revision 0

\subsection{SELECTING GLASSES TO REFINE THE NEPHELINE DISCRIMINATOR}

In support of SB4 processing, only one sludge option is considered here: Case 15C Blend 1, which is a "sludge-only" (i.e., no additional ARP stream) based flowsheet. ${ }^{2}$ This option is seen as providing the most likely representation of SB4. It should be noted that although the primary focus is on SB4, the Phase 3 data will be applicable to other high $\mathrm{Al}_{2} \mathrm{O}_{3}$ waste streams (i.e., SB5).

This option was combined with the four frits described in Table 3-2 in a paper study where the PCCS measurement acceptability region (MAR) assessments and nepheline discriminator values were determined for a WL range of 25 to $60 \% .^{3}$ Table 4-1 summarizes the MAR assessments for these glass systems. The limiting factor is indicated in the table for each glass that falls outside of the acceptability criteria. These factors are listed as "Neph" for predicted nepheline formation, "TL" for liquidus temperature, and "lvisc" for low viscosity.

Table 4-1 shows that the Frit 418 and Frit 425 systems are limited by predicted nepheline crystallization at WLs of $47 \%$ and $45 \%$, respectively. For the Frit 501 system, liquidus temperature limits access to WLs of $48 \%$ and above, with nepheline formation predicted at WLs of $49 \%$ and above. Liquidus temperature, viscosity, and predicted nepheline crystallization are all limiting factors for the Frit 502 system at WLs of $49 \%$ and above.

To support test objectives, WLs that bounded where the prediction of nepheline was an issue were to be targeted. Given that and the fact that some systems were "non-nepehline" limited, some of the targeted Phase 3 glasses would be selected that would not be acceptable from a PCCS MAR perspective. More specifically, select glasses will be targeted that bound nepheline formation issues, but fail other processing constraints. 
Table 4-1. MAR assessments for the SB4 candidate systems of interest.

\begin{tabular}{|c|c|c|c|c|c|}
\hline Sludge Option & $\begin{array}{c}\text { Waste } \\
\text { Loading (\%) } \\
\end{array}$ & Frit 418 & Frit 425 & Frit 501 & Frit 502 \\
\hline Case 15C Blend 1 & 25 & - & - & - & - \\
\hline Case 15C Blend 1 & 26 & - & - & - & - \\
\hline Case 15C Blend 1 & 27 & - & - & - & - \\
\hline Case 15C Blend 1 & 28 & - & - & - & - \\
\hline Case 15C Blend 1 & 29 & - & - & - & - \\
\hline Case 15C Blend 1 & 30 & - & - & - & - \\
\hline Case 15C Blend 1 & 31 & - & - & - & - \\
\hline Case 15C Blend 1 & 32 & - & - & - & - \\
\hline Case 15C Blend 1 & 33 & - & - & - & - \\
\hline Case 15C Blend 1 & 34 & - & - & - & - \\
\hline Case 15C Blend 1 & 35 & - & - & - & - \\
\hline Case 15C Blend 1 & 36 & - & - & - & - \\
\hline Case 15C Blend 1 & 37 & - & - & - & - \\
\hline Case 15C Blend 1 & 38 & - & - & - & - \\
\hline Case 15C Blend 1 & 39 & - & - & - & - \\
\hline Case 15C Blend 1 & 40 & - & - & - & - \\
\hline Case 15C Blend 1 & 41 & - & - & - & - \\
\hline Case 15C Blend 1 & 42 & - & - & - & - \\
\hline Case 15C Blend 1 & 43 & - & - & - & - \\
\hline Case 15C Blend 1 & 44 & - & - & - & - \\
\hline Case 15C Blend 1 & 45 & - & Neph & - & - \\
\hline Case 15C Blend 1 & 46 & - & Neph & - & - \\
\hline Case 15C Blend 1 & 47 & Neph & Neph & - & - \\
\hline Case 15C Blend 1 & 48 & Neph & Neph & $\mathrm{TL}$ & - \\
\hline Case 15C Blend 1 & 49 & TL, Neph & lvisc, Neph & TL, Neph & TL, lvisc, Neph \\
\hline Case 15C Blend 1 & 50 & TL, Neph & lvisc, Neph & TL, Neph & TL, lvisc, Neph \\
\hline Case 15C Blend 1 & 51 & TL, Neph & TL, lvisc, Neph & TL, lvisc,Neph & TL, lvisc, Neph \\
\hline Case 15C Blend 1 & 52 & TL, Neph & TL, lvisc, Neph & TL, lvisc, Neph & TL, lvisc, Neph \\
\hline Case 15C Blend 1 & 53 & TL, Neph & TL, lvisc, Neph & TL, lvisc, Neph & TL, lvisc, Neph \\
\hline Case 15C Blend 1 & 54 & TL, lvisc, Neph & TL, lvisc, Neph & TL, lvisc, Neph & TL, lvisc, Neph \\
\hline Case 15C Blend 1 & 55 & TL, lvisc, Neph & TL, lvisc, Neph & TL, lvisc, Neph & TL, lvisc, Neph \\
\hline Case 15C Blend 1 & 56 & TL, lvisc, Neph & TL, lvisc, Neph & TL, lvisc, Neph & TL, lvisc, Neph \\
\hline Case 15C Blend 1 & 57 & TL, lvisc, Neph & TL, lvisc, Neph & TL, lvisc, Neph & TL, lvisc, Neph \\
\hline Case 15C Blend 1 & 58 & TL, lvisc, Neph & TL, lvisc, Neph & TL, lvisc, Neph & TL, lvisc, Neph \\
\hline Case 15C Blend 1 & 59 & TL, lvisc, Neph & TL, lvisc, Neph & TL, lvisc, Neph & TL, lvisc, Neph \\
\hline Case 15C Blend 1 & 60 & TL, lvisc, Neph & TL, lvisc, Neph & TL, lvisc, Neph & TL, lvisc, Neph \\
\hline
\end{tabular}


In selecting the Phase 3 glasses, a window of nepheline discriminator values was chosen based on the Phase 1 and 2 results. The lower end of the window was set at a value of 0.59 , where the glasses should begin to have a measurable difference in PCT response between the quenched and ccc specimens, but will not have unacceptable (EA-like) durability. The upper end of the window was set at 0.62 , as the previous phases of the work have shown this value to be a reliable indicator of the potential for nepheline crystallization in ccc glasses.

Table 4-2 lists the nepheline discriminator values for the sludge-frit systems under study, developed through the earlier paper study. ${ }^{3}$ WL levels for each of the four frits were chosen at nepheline discriminator values of just above 0.62 and just below 0.60 , as described above. These are shaded in Table 4-2. Note that some of the chosen WL levels will produce glasses that have an unacceptable $T_{L}$ or viscosity based on the PCCS MAR results given in Table 4-1. This was intentionally disregarded in favor of concentrating on the potential for nepheline formation.

In addition, glass specimens at WLs of 35 and 40\% (a range more likely to be used by DWPF) will be prepared and analyzed to contribute needed data to the ComPro ${ }^{\mathrm{TM}}$ database in anticipation of a variability study for SB4.

The 16 glass compositions generated by this process are given in Table 4-3. Unique identifiers for these glasses are provided in the first row of the table, and the value of the nepheline discriminator for each glass is also included. These glasses are to be batched and fabricated using standard procedures. Visual observations and other analytical techniques are to be used, as needed, to assess the presence of crystals and, specifically, a nepheline phase. The durability of these glasses (for both quenched and ccc

treatments) is to be measured using the ASTM PCT Method A. ${ }^{17}$ The results from these efforts are to be documented in a subsequent report. 
Table 4-2. Nepheline discriminator values over a range of waste loadings for the four frits studied.

\begin{tabular}{|c|c|c|c|c|}
\hline $\begin{array}{c}\text { Waste Loading } \\
(\%)\end{array}$ & Frit 418 & Frit 425 & Frit 501 & Frit 502 \\
\hline 25 & 0.766 & 0.746 & 0.790 & 0.790 \\
\hline 26 & 0.760 & 0.740 & 0.783 & 0.783 \\
\hline 27 & 0.754 & 0.734 & 0.776 & 0.776 \\
\hline 28 & 0.747 & 0.728 & 0.770 & 0.770 \\
\hline 29 & 0.741 & 0.722 & 0.763 & 0.763 \\
\hline 30 & 0.735 & 0.716 & 0.756 & 0.756 \\
\hline 31 & 0.728 & 0.709 & 0.749 & 0.749 \\
\hline 32 & 0.722 & 0.703 & 0.742 & 0.742 \\
\hline 33 & 0.715 & 0.697 & 0.735 & 0.735 \\
\hline 34 & 0.708 & 0.690 & 0.728 & 0.728 \\
\hline 35 & 0.702 & 0.684 & 0.721 & 0.721 \\
\hline 36 & 0.695 & 0.677 & 0.714 & 0.714 \\
\hline 37 & 0.688 & 0.671 & 0.707 & 0.707 \\
\hline 38 & 0.681 & 0.664 & 0.699 & 0.699 \\
\hline 39 & 0.674 & 0.657 & 0.692 & 0.692 \\
\hline 40 & 0.667 & 0.650 & 0.685 & 0.685 \\
\hline 41 & 0.660 & 0.643 & 0.677 & 0.677 \\
\hline 42 & 0.653 & 0.637 & 0.670 & 0.670 \\
\hline 43 & 0.646 & 0.630 & 0.662 & 0.662 \\
\hline 44 & 0.639 & 0.622 & 0.654 & 0.654 \\
\hline 45 & 0.631 & 0.615 & 0.647 & 0.647 \\
\hline 46 & 0.624 & 0.608 & 0.639 & 0.639 \\
\hline 47 & 0.616 & 0.601 & 0.631 & 0.631 \\
\hline 48 & 0.609 & 0.594 & 0.623 & 0.623 \\
\hline 49 & 0.601 & 0.586 & 0.615 & 0.615 \\
\hline 50 & 0.593 & 0.579 & 0.607 & 0.607 \\
\hline 51 & 0.586 & 0.571 & 0.599 & 0.599 \\
\hline 52 & 0.578 & 0.563 & 0.591 & 0.591 \\
\hline 53 & 0.570 & 0.556 & 0.582 & 0.582 \\
\hline 54 & 0.562 & 0.548 & 0.574 & 0.574 \\
\hline 55 & 0.554 & 0.540 & 0.565 & 0.565 \\
\hline 56 & 0.546 & 0.532 & 0.557 & 0.557 \\
\hline 57 & 0.537 & 0.524 & 0.548 & 0.548 \\
\hline 58 & 0.529 & 0.516 & 0.539 & 0.539 \\
\hline 59 & 0.520 & 0.508 & 0.531 & 0.531 \\
\hline 60 & 0.512 & 0.500 & 0.522 & 0.522 \\
\hline
\end{tabular}


Table 4-3. Compositions of Selected Glasses for SB4 Case 15C Blend 1

(in wt\%)

\begin{tabular}{|c|c|c|c|c|c|c|c|c|c|c|c|c|c|c|c|c|}
\hline Glass ID & $\begin{array}{c}\text { NEPH } \\
3-41 \\
\end{array}$ & $\begin{array}{c}\text { NEPH } \\
3-42 \\
\end{array}$ & $\begin{array}{c}\text { NEPH } \\
3-43 \\
\end{array}$ & $\begin{array}{c}\text { NEPH } \\
3-44 \\
\end{array}$ & $\begin{array}{c}\text { NEPH } \\
3-45 \\
\end{array}$ & $\begin{array}{c}\text { NEPH } \\
3-46 \\
\end{array}$ & $\begin{array}{c}\text { NEPH } \\
3-47 \\
\end{array}$ & $\begin{array}{c}\text { NEPH } \\
3-48 \\
\end{array}$ & $\begin{array}{c}\text { NEPH } \\
3-49 \\
\end{array}$ & $\begin{array}{c}\text { NEPH } \\
3-50 \\
\end{array}$ & $\begin{array}{c}\text { NEPH } \\
3-51 \\
\end{array}$ & $\begin{array}{c}\text { NEPH } \\
3-52 \\
\end{array}$ & $\begin{array}{c}\text { NEPH } \\
3-53 \\
\end{array}$ & $\begin{array}{c}\text { NEPH } \\
3-54 \\
\end{array}$ & $\begin{array}{c}\text { NEPH } \\
3-55 \\
\end{array}$ & $\begin{array}{c}\text { NEPH } \\
3-56 \\
\end{array}$ \\
\hline Frit ID & 418 & 418 & 418 & 418 & 501 & 501 & 501 & 501 & 425 & 425 & 425 & 425 & 502 & 502 & 502 & 502 \\
\hline \%WL & 35 & 40 & 46 & 50 & 35 & 40 & 47 & 51 & 35 & 40 & 44 & 48 & 35 & 40 & 48 & 51 \\
\hline $\begin{array}{l}\text { nepheline } \\
\text { discrim. }\end{array}$ & 0.702 & 0.667 & 0.624 & 0.593 & 0.721 & 0.685 & 0.631 & 0.599 & 0.684 & 0.650 & 0.622 & 0.594 & 0.721 & 0.685 & 0.623 & 0.599 \\
\hline $\mathrm{Al}_{2} \mathrm{O}_{3}$ & 8.682 & 9.922 & 11.411 & 12.403 & 8.682 & 9.922 & 11.659 & 12.651 & 8.682 & 9.922 & 10.915 & 11.907 & 8.682 & 9.922 & 11.907 & 12.651 \\
\hline $\mathrm{B}_{2} \mathrm{O}_{3}$ & 5.200 & 4.800 & 4.320 & 4.000 & 5.850 & 5.400 & 4.770 & 4.410 & 5.200 & 4.800 & 4.480 & 4.160 & 5.200 & 4.800 & 4.160 & 3.920 \\
\hline $\mathrm{BaO}$ & 0.044 & 0.050 & 0.058 & 0.063 & 0.044 & 0.050 & 0.059 & 0.064 & 0.044 & 0.050 & 0.056 & 0.061 & 0.044 & 0.050 & 0.061 & 0.064 \\
\hline $\mathrm{CaO}$ & 0.836 & 0.955 & 1.098 & 1.194 & 0.836 & 0.955 & 1.122 & 1.218 & 0.836 & 0.955 & 1.051 & 1.146 & 0.836 & 0.955 & 1.146 & 1.218 \\
\hline $\mathrm{Ce}_{2} \mathrm{O}_{3}$ & 0.052 & 0.060 & 0.069 & 0.075 & 0.052 & 0.060 & 0.070 & 0.076 & 0.052 & 0.060 & 0.066 & 0.072 & 0.052 & 0.060 & 0.072 & 0.076 \\
\hline $\mathrm{Cr}_{2} \mathrm{O}_{3}$ & 0.074 & 0.085 & 0.098 & 0.106 & 0.074 & 0.085 & 0.100 & 0.108 & 0.074 & 0.085 & 0.093 & 0.102 & 0.074 & 0.085 & 0.102 & 0.108 \\
\hline $\mathrm{CuO}$ & 0.021 & 0.024 & 0.028 & 0.030 & 0.021 & 0.024 & 0.028 & 0.031 & 0.021 & 0.024 & 0.026 & 0.029 & 0.021 & 0.024 & 0.029 & 0.031 \\
\hline $\mathrm{Fe}_{2} \mathrm{O}_{3}$ & 9.298 & 10.626 & 12.220 & 13.283 & 9.298 & 10.626 & 12.486 & 13.548 & 9.298 & 10.626 & 11.689 & 12.751 & 9.298 & 10.626 & 12.751 & 13.548 \\
\hline $\mathrm{K}_{2} \mathrm{O}$ & 0.120 & 0.138 & 0.158 & 0.172 & 0.120 & 0.138 & 0.162 & 0.175 & 0.120 & 0.138 & 0.151 & 0.165 & 0.120 & 0.138 & 0.165 & 0.175 \\
\hline $\mathrm{La}_{2} \mathrm{O}_{3}$ & 0.038 & 0.043 & 0.050 & 0.054 & 0.038 & 0.043 & 0.051 & 0.055 & 0.038 & 0.043 & 0.048 & 0.052 & 0.038 & 0.043 & 0.052 & 0.055 \\
\hline $\mathrm{Li}_{2} \mathrm{O}$ & 5.200 & 4.800 & 4.320 & 4.000 & 6.500 & 6.000 & 5.300 & 4.900 & 5.200 & 4.800 & 4.480 & 4.160 & 7.150 & 6.600 & 5.720 & 5.390 \\
\hline $\mathrm{MgO}$ & 0.873 & 0.998 & 1.148 & 1.248 & 0.873 & 0.998 & 1.173 & 1.273 & 0.873 & 0.998 & 1.098 & 1.198 & 0.873 & 0.998 & 1.198 & 1.273 \\
\hline $\mathrm{MnO}$ & 1.918 & 2.192 & 2.521 & 2.740 & 1.918 & 2.192 & 2.576 & 2.795 & 1.918 & 2.192 & 2.411 & 2.630 & 1.918 & 2.192 & 2.630 & 2.795 \\
\hline $\mathrm{Na}_{2} \mathrm{O}$ & 12.928 & 13.632 & 14.477 & 15.040 & 10.978 & 11.832 & 13.027 & 13.711 & 14.228 & 14.832 & 15.315 & 15.798 & 10.978 & 11.832 & 13.198 & 13.711 \\
\hline $\mathrm{NiO}$ & 0.552 & 0.631 & 0.726 & 0.789 & 0.552 & 0.631 & 0.741 & 0.804 & 0.552 & 0.631 & 0.694 & 0.757 & 0.552 & 0.631 & 0.757 & 0.804 \\
\hline $\mathrm{PbO}$ & 0.032 & 0.036 & 0.042 & 0.045 & 0.032 & 0.036 & 0.043 & 0.046 & 0.032 & 0.036 & 0.040 & 0.043 & 0.032 & 0.036 & 0.043 & 0.046 \\
\hline $\mathrm{SO}_{4}$ & 0.468 & 0.535 & 0.615 & 0.669 & 0.468 & 0.535 & 0.629 & 0.682 & 0.468 & 0.535 & 0.589 & 0.642 & 0.468 & 0.535 & 0.642 & 0.682 \\
\hline $\mathrm{SiO}_{2}$ & 50.840 & 47.245 & 42.932 & 40.057 & 50.840 & 47.245 & 42.213 & 39.338 & 49.540 & 46.045 & 43.250 & 40.454 & 50.840 & 47.245 & 41.494 & 39.338 \\
\hline $\mathrm{ThO}_{2}$ & 0.023 & 0.026 & 0.030 & 0.033 & 0.023 & 0.026 & 0.031 & 0.034 & 0.023 & 0.026 & 0.029 & 0.032 & 0.023 & 0.026 & 0.032 & 0.034 \\
\hline $\mathrm{TiO}_{2}$ & 0.009 & 0.011 & 0.012 & 0.013 & 0.009 & 0.011 & 0.013 & 0.014 & 0.009 & 0.011 & 0.012 & 0.013 & 0.009 & 0.011 & 0.013 & 0.014 \\
\hline $\mathrm{U}_{3} \mathrm{O}_{8}$ & 2.674 & 3.056 & 3.515 & 3.820 & 2.674 & 3.056 & 3.591 & 3.897 & 2.674 & 3.056 & 3.362 & 3.667 & 2.674 & 3.056 & 3.667 & 3.897 \\
\hline $\mathrm{ZnO}$ & 0.034 & 0.039 & 0.045 & 0.049 & 0.034 & 0.039 & 0.046 & 0.050 & 0.034 & 0.039 & 0.043 & 0.047 & 0.034 & 0.039 & 0.047 & 0.050 \\
\hline $\mathrm{ZrO}_{2}$ & 0.083 & 0.095 & 0.109 & 0.119 & 0.083 & 0.095 & 0.111 & 0.121 & 0.083 & 0.095 & 0.104 & 0.114 & 0.083 & 0.095 & 0.114 & 0.121 \\
\hline
\end{tabular}


WSRC-TR-2006- 00053

Revision 0

\subsection{SUMMARY}

Savannah River National Laboratory's frit development effort for SB4 is being driven by the most current CBU option for this sludge, referred to as Case 15C Blend 1. Candidate frits have been identified for this option via a paper study approach developed by Peeler and Edwards ${ }^{15}$ with the intent of down-selecting to a set of key frits whose operating windows (i.e., WL intervals that meet PCCS MAR criteria) are robust to and/or selectively optimal for this sludge option. The primary frits that appear attractive on paper (i.e., down-selected via the paper study) are now being incorporated into this experimental study.

The potential for the formation of a nepheline primary crystalline phase is an important factor in frit development for SB4, due to the high $\mathrm{Al}_{2} \mathrm{O}_{3}$ content of this sludge. Based upon earlier work by Li et al., glasses that do not satisfy the constraint:

$$
\frac{\mathrm{SiO}_{2}}{\mathrm{SiO}_{2}+\mathrm{Na}_{2} \mathrm{O}+\mathrm{Al}_{2} \mathrm{O}_{3}}>0.62
$$

where the oxides are expressed as mass fractions in the glass, will precipitate nepheline as their primary crystalline phase, hindering the durability of the glass.

Based on the most recent compositional projection from the CBU for SB4 (Case 15C Blend 1), 16 glasses have been selected to complement the earlier work ${ }^{4-6}$ by continuing the investigation into the ability of the above constraint to predict the occurrence of a nepheline primary crystalline phase for SB4 glasses and into the impact of such phases on the durability of the SB4 glasses. Glasses were selected to cover WLs which tightly bound the nepheline discriminator value of 0.62 , with the intent of refining this value to a level of confidence where it can be incorporated into offline administrative controls and/or the PCCS to support SME acceptability decisions. In addition, glass specimens at WLs of 35 and $40 \%$ will be prepared and analyzed to contribute needed data to the $\mathrm{ComPro}^{\mathrm{TM}}$ database in anticipation of a variability study for SB4.

The glasses in Table 4-3 are to batched and fabricated using standard procedures. Visual observations and other analytical techniques are to be used, as needed, to assess the presence of crystals with specific interest in the nepheline primary phase. The durability of these glasses (for both quenched and centerline canister cooled versions) is to be measured using the ASTM PCT Method A. The results from these efforts are to be documented in a subsequent report.

The results of this study will provide valuable input for the frit development efforts and subsequent feedback to the CBU regarding the relative viability of the current SB4 option under consideration. The refined nepheline discriminator value will provide a guideline for the avoidance of nepheline crystallization in SB4 glasses and aid in down-selection of frit compositions. These data will be combined with the results of melt rate studies and a paper study of the frits' robustness with regard to variability in the sludge composition to provide an optimized frit recommendation to DWPF for immobilization of SB4. 
WSRC-TR-2006- 00053

Revision 0

\subsection{REFERENCES}

1. Li, H., P. Hrma, J.D. Vienna, M. Qian, Y. Su, and D.E. Smith, "Effects of $\mathrm{Al}_{2} \mathrm{O}_{3}, \mathrm{~B}_{2} \mathrm{O}_{3}, \mathrm{Na}_{2} \mathrm{O}$, and $\mathrm{SiO}_{2}$ on Nepheline Formation in Borosilicate Glasses: Chemical and Physical Correlations," Journal of Non-Crystalline Solids, 331 202-216 (2003).

2. Shah, H.B., Estimate of Sludge Batch $\mathbf{4}$ Calcine Composition: Additional Cases for Final Recommendation, CBU-PIT-2006-0001, Westinghouse Savannah River Company, Aiken, South Carolina (2006).

3. $\quad$ Peeler, D.K. and T.B. Edwards, Model Based Assessments for the Baseline Sludge Batch 4 (Case 15C) Flowsheet, WSRC-TR-2006-00049, Revision 0, Washington Savannah River Company, Aiken, South Carolina (2006).

4. $\quad$ Peeler, D.K. and T.B. Edwards, Frit Development Efforts for Sludge Batch 4: Model-Based Assessments, WSRC-TR-2005-00103, Revision 0, Westinghouse Savannah River Company, Aiken, South Carolina (2005).

5. Peeler, D.K. and T.B. Edwards, The Impact of the Actinide Removal Process (ARP) on the Sludge Batch 4 Projected Operating Windows, WSRC-TR-2005-00123, Revision 0, Westinghouse Savannah River Company, Aiken, South Carolina (2005).

6. $\quad$ Edwards, T.B. and D.K. Peeler, Nepheline Formation Potential in Sludge Batch 4 (SB4) and Its Impact on Durability: Selecting Glasses for a Phase 2 Study, WSRC-TR-2005-00370, Revision 0, Westinghouse Savannah River Company, Aiken, South Carolina (2005).

7. Lilliston, G.R., Development of Elemental Sludge Compositions for Variations of Sludge Batch 4 (SB4), CBU-PIT-2004-00011, Revision 1, Westinghouse Savannah River Company, Aiken, South Carolina (2005).

8. Elder, H.H., Estimate of Sludge Batch 4 Calcine Composition, CBU-PIT-2005-00134, Revision 0, Westinghouse Savannah River Company, Aiken, South Carolina (2005).

9. Elder, H.H., Estimate of Sludge Batch 4 Calcine Composition Additional Cases, CBU-PIT2005-00176, Revision 0, Westinghouse Savannah River Company, Aiken, South Carolina (2005).

10. Brown, K.G., R.L. Postles, and T.B. Edwards, SME Acceptability Determination for DWPF Process Control, WSRC-TR-95-00364, Revision 4, Westinghouse Savannah River Company, Aiken, South Carolina (2002).

11. Washburn, F.A., Technical Task Request: Sludge Batch 4 and MCU Frit Optimization, HLW/DWPF/TTR-2004-0025, Revision 0, Westinghouse Savannah River Company, Aiken, South Carolina (2004).

12. Washburn, F.A., Technical Task Request: Sludge Batch $\mathbf{4}$ and MCU Glass Variability Studies with Simulants, HLW/DWPF/TTR-2004-0027, Revision 0, Westinghouse Savannah River Company, Aiken, South Carolina (2004). 
13. Peeler, D.K., Task Technical \& QA Plan: Sludge Batch and MCU Frit Optimization, WSRCRP-2004-00746, Revision 0, Westinghouse Savannah River Company, Aiken, South Carolina (2004).

14. Peeler, D.K., Task Technical \& QA Plan: Sludge Batch 4 and MCU Glass Variability Studies with Simulants, WSRC-RP-2004-00747, Revision 0, Westinghouse Savannah River Company, Aiken, South Carolina (2004).

15. Peeler, D.K. and T.B. Edwards, Frit Development Effort for SB4: Nominal and Variation Stage Assessments, WSRC-TR-2005-00372, Revision 0, Westinghouse Savannah River Company, Aiken, South Carolina (2005).

16. Jantzen, C.M., J.B. Picket, K.G. Brown, T.B. Edwards, and D.C. Beam, Process/Product Models for the Defense Waste Processing Facility (DWPF): Part I. Predicting Glass Durability from Composition Using a Thermodynamic Hydration Energy Reaction Model (THERMO), WSRC-TR-93-672, Revision 1, Westinghouse Savannah River Company, Aiken, South Carolina (1995).

17. ASTM, Standard Test Methods for Determining Chemical Durability of Nuclear Waste Glasses: The Product Consistency Test (PCT), ASTM C-1285-2002, (2002).

18. Peeler, D.K. and T.B. Edwards, A Preliminary Assessment of the Need for a Sludge Batch 4 Variability Study, WSRC-TR-2005-00122, Revision 0, Westinghouse Savannah River Company, Aiken, South Carolina (2005).

19. Taylor, A.S., T.B. Edwards, J.C. George, T.K. Snyder, and D.K. Peeler, The SRNL Composition - Properties (ComPro ${ }^{\mathrm{TM}}$ ) Database, WSRC-RP-2004-00704, Revision 0, Westinghouse Savannah River Company, Aiken, South Carolina (2004).

20. Bickford, D.F. and C.M. Jantzen, "Devitrification of SRL Defense Waste Glass," Sci. Basis for Nuclear Waste Management VII, edited by G.L. McVay, 557-565 (1984).

21. Cicero, C.A., S.L. Marra, and M.K. Andrews, Phase Stability Determinations of DWPF Waste Glasses (U), WSRC-TR-93-00227, Revision 0, Westinghouse Savannah River Company, Aiken, South Carolina (1993).

22. Kim, D.S., D.K. Peeler, and P. Hrma, "Effect of Crystallization on the Chemical Durability of Simulated Nuclear Waste Glasses," Environmental Issues and Waste Management Technologies in the Ceramic and Nuclear Industries, Ceramic Transactions, 61 177-185 (1995).

23. Marra, S.L. and C.M. Jantzen, Characterization of Projected DWPF Glass Heat Treated to Simulate Canister Centerline Cooling, WSRC-TR-92-142, Revision 1, Westinghouse Savannah River Company, Aiken, South Carolina (1993).

24. Li, H., J.D. Vienna, P. Hrma, D.E. Smith, and M.J. Schwieger, "Nepheline Precipitation in HighLevel Waste Glasses - Compositional Effects and Impact on the Waste Form Acceptability," Mat. Res. Soc. Proc., 465 261-268 (1997).

25. Riley, B.J., J.A. Rosario, and P. Hrma, Impact of HLW Glass Crystallinity on the PCT Response, PNNL-13491, Pacific Northwest National Laboratory, Richland, Washington (2001). 
26. Peeler, D.K., T.B. Edwards, and T.H. Lorier, Nepheline Formation Potential in Sludge Batch (SB4) Glasses, WSRC-TR-2005-00153, Revision 0, Westinghouse Savannah River Company, Aiken, South Carolina (2005).

27. Peeler, D.K., T.B. Edwards, I.A. Reamer, and R.J. Workman, Nepheline Formation Study for Sludge Batch 4 (SB4): Phase 1 Experimental Results, WSRC-TR-2005-00371, Revision 0, Westinghouse Savannah River Company, Aiken, South Carolina (2005).

28. Jantzen, C.M., N.E. Bibler, D.C. Beam, C.L. Crawford, and M.A. Pickett, Characterization of the Defense Waste Processing Facility (DWPF) Environmental Assessment (EA) Glass Standard Reference Material, WSRC-TR-92-346, Revision 1, Westinghouse Savannah River Company, Aiken, South Carolina (1993).

29. Peeler, D.K., T.B. Edwards, D.R. Best, I.A. Reamer, and R.J. Workman, Nepheline Formation Study for Sludge Batch 4 (SB4): Phase 2 Experimental Results, WSRC-TR-2006-00006, Revision 0, Westinghouse Savannah River Company, Aiken, South Carolina (2006).

30. Stone, M.E. and J.E. Josephs, Melt Rate Improvement for DWPF MB3: Melt Rate Furnace Testing (U), WSRC-TR-2001-00146, Revision 0, Westinghouse Savannah River Company, Aiken, South Carolina (2001). 


\section{Distribution:}

J.E. Marra, SRNL

R.E. Edwards, SRNL

D.A. Crowley, 999-W

S.L. Marra, 773-A

T.B. Calloway, 999-W

N.E. Bibler, SRNL

C.M. Jantzen, SRNL

J.R. Harbour, 773-42A

G.G. Wicks, SRNL

R.C. Tuckfield, 773-42A

D.K. Peeler, 999-W

T.B. Edwards, 773-42A

K.M. Fox, 773-A

C.C. Herman, 773-42A

A.S. Choi, 999-W
M.E. Smith, 773-42A

M.E. Stone, 999-W

D.H. Miller, 999-W

M.J. Barnes, 999-W

M.S. Miller, 704-S

J.E. Occhipinti, 704-S

T.M. Jones, 999-W

R.M. Hoeppel, 704-27S

B.A. Davis, 704-27S

P.M. Patel, 704-27S

J.F. Iaukea, 704-30S

J.W. Ray, 704-S

M.A. Rios-Armstrong, 766-H

W.B. Van-Pelt, 704-S

H.B. Shah, 766-H 